УДК 621.926.3

DOI: $10.37128 / 2520-6168-2020-4-9$

Vol. 111, No 4 / 2020

\title{
INTENSIFICATION OF MIXING OF HETEROGENEOUS FOOD MIXTURES UNDER THE IMPACT OF ULTRASONIC VIBRATIONS
}

\author{
I. Sevostianov, Doctor of Technical Sciences, Full Professor \\ S. Kraevsky, Post-graduate Student \\ Vinnytsia National Agrarian University \\ Севостьянов Іван В'ячеславович, доктор технічних наук, професор \\ Краєвський Сергій Олександрович, аспірант \\ Вінницький національний аграрний університет
}

There is known equipment for mixing of heterogeneous food mixtures analyzed in this article. Some part of this equipment provides qualitative mixing at macro-level (mixing of large portions of processed material), for example, paddle, propeller, turbine, anchor, screw, gravitation and drum mixers. Another part of mixing machines on the contrary, allows to achieve of effective micro-level mixing (mutual movements of adjacent particles of material) - vibratory and centrifugal mixers. In some cases there is important to provide well mixing both at macro- and at micro-level, when it is accompanied by thermal, diffusion or chemical processes and from its efficiency depend energy expenses and qualitative characteristics of product. Therefore, a task of elaboration of schemes of improved apparatuses for effective macro-and micro-mixing of dry and liquid multi-component food materials is resolved in the article. Authors are proposing to create these apparatuses at the base of well known equipment - gravitation and screw mixers by way of their additional equipping with serial electromagnetic vibro-exciters of ultrasonic oscillations. As a result, a main drive of a base mixer will provide working process at macro-level and an additional drive-micro-level movements of material particles. The proposed apparatuses have a simple and reliable construction, don't consist of original parts and at the same time, provide necessary efficiency of working process. Equations of movements of processed components particles in course of their different loading stages, with examination of physicalmechanical properties of the components are also presented in the article. These equations can be used as a base for further creation of methods of design calculation of proposed apparatuses.

Key words: heterogeneous food mixtures, mixing at macro- and micro-level, electromagnetic vibration exciter, ultrasonic oscillations.

F. 7. Fig. 9. Ref. 8 .

\section{Problem formulation}

Mixing processes of heterogeneous dispersed systems are wide spread in food and processing industries. A lot of attention is paid for rationalization of these processes in order to raise their productivity, to reduce energy consumption, to increase the degree of uniformity of the final mixture. There is a large number of known equipment, that provides effective mixing at the macro-level (movement of large and medium volumes of processed material): paddle, propeller, turbine, frame, anchor, screw, gravitation and drum mixers. At the same time, vibratory and centrifugal mixers realize effective working process mainly at the micro-level (mutual movements of adjacent particles of the mixture of some volumes portion). Therefore, the actual task is to increase efficiency of an equipment for mixing of heterogeneous dry and liquid food mixtures both at the macro- and micro-level.

\section{Analysis of last researches and publications}

Most wide spread and universal equipment for macro-level mixing is presented at the fig. $1[1,2]$. The paddle mixers (fig. 1, a) have simple and reliable construction, but do not provide sufficient mobility of processed components particles in an axial direction.

The propeller mixers (fig. 1, b) can create not only radial, but also an axial movement of processed components particles in the apparatus corpse. Their shortcomings are: complex and non technological form of executive element and insufficient mixing of particles at micro-level. The same shortcomings have turbine mixers (fig 1, c). 
The anchor mixer (fig. 2, a) [2,3] provides relatively low productivity of working process and intended mainly for preparation of liquid mixtures in course of their simultaneous heating.
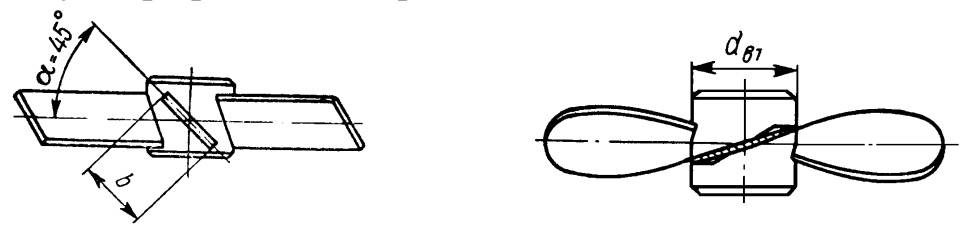

$A-A$

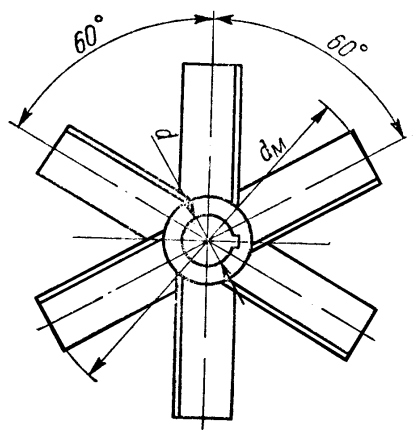

a)

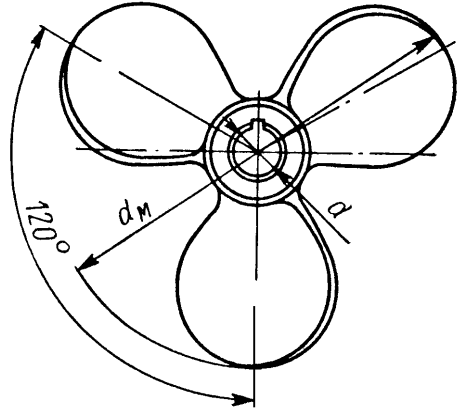

b)


c)

Fig. 1. The executive elements of paddle (a), propeller (b) and turbine (c) mixers


a)

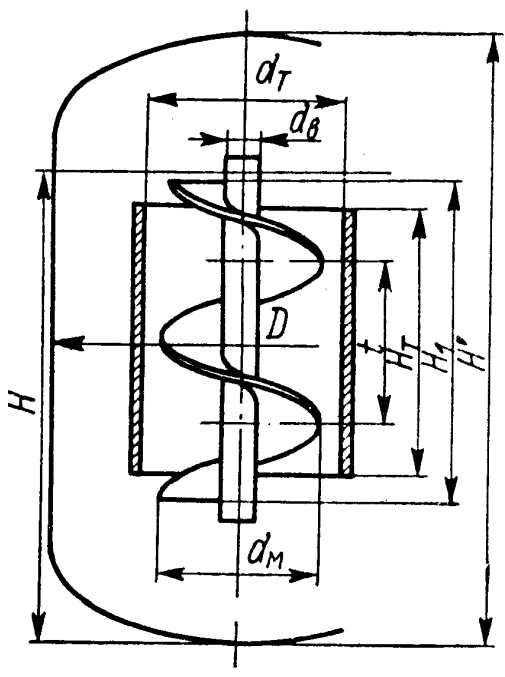

b)

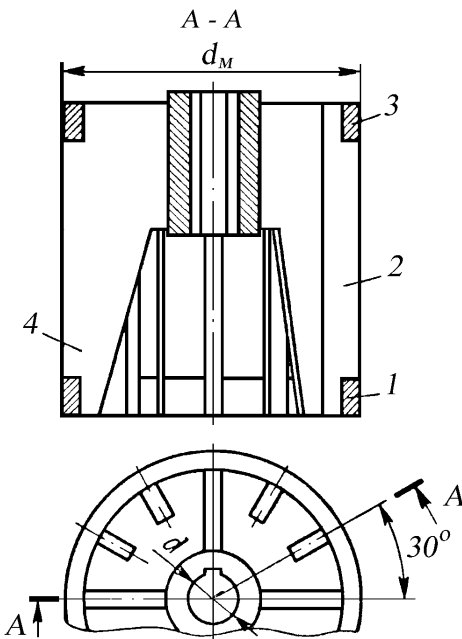

c)

Fig. 2. Schemes of anchor (a), screw (b) and cage (c) mixers: 1, 3 -bandage; 2 -flat blade; 4 -figured blade

The screw mixers (fig. 2, b) [2] are one from most effective, reliable, universal types of equipment for mixing of liquid and dry heterogeneous dispersed systems. Their shortcomings are: availability of a non technological in manufacturing and repair executive element - a screw, which realizes macro-level working process mainly in central axial layers of processed components.

The cage mixers (fig. 2, c) [2] provide higher, than two previous types of mixers productivity of working process at macro-level, but have more complex construction.

At the fig. 3 [2] are presented construction of a modern equipment for continuous mixing of heterogeneous dispersed systems. There is obvious, that executive elements of this equipment have enough complex configuration, high price, besides these elements are sensitive to abrasive wear and to overloading. General destination of this equipment is macro-level mixing of liquid heterogeneous dispersed components.

At the fig. 4 are presented constructions of gravitation mixers [2], which by our notion belong to one from most prospective type of an equipment for continuous macro-level mixing of heterogeneous dry dispersed systems, owing to its design simplicity, high reliability and productivity. The main advantage of this equipment, by our notion, is absence of energy expenses for realization of working process. 


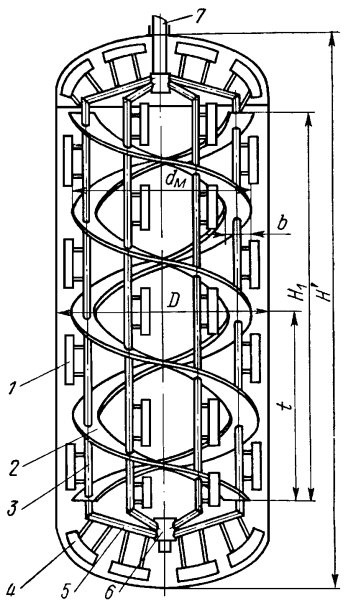

a)



e)



b)

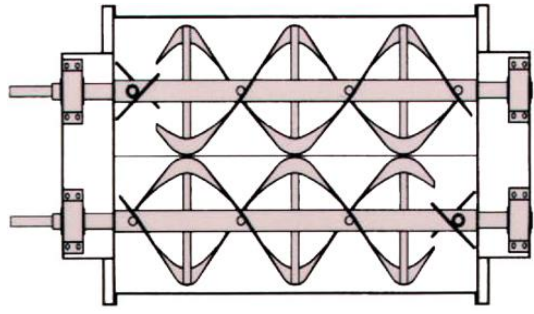

c)

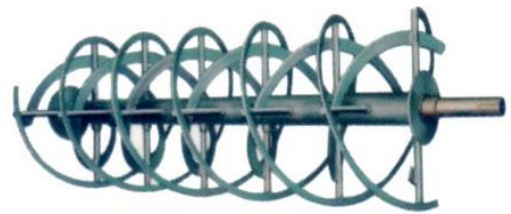

d)
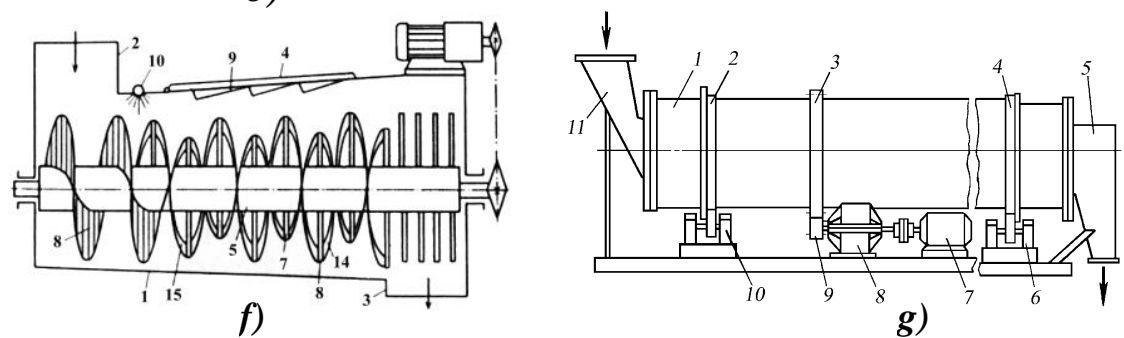

Fig. 3. Construction of modern equipment for continuous mixing of heterogeneous dispersed systems: $a$-tape mixer; $b$ - «Lödige» mixer; $c$-two-shaft mixer; $d$ - executive element of "Münch Edelstahl»" mixer; $e$-executive element of «Uni-Mix» from «Skiold»; f-mixer HPB from "Sprout-Matador»; g-drum mixer



a)

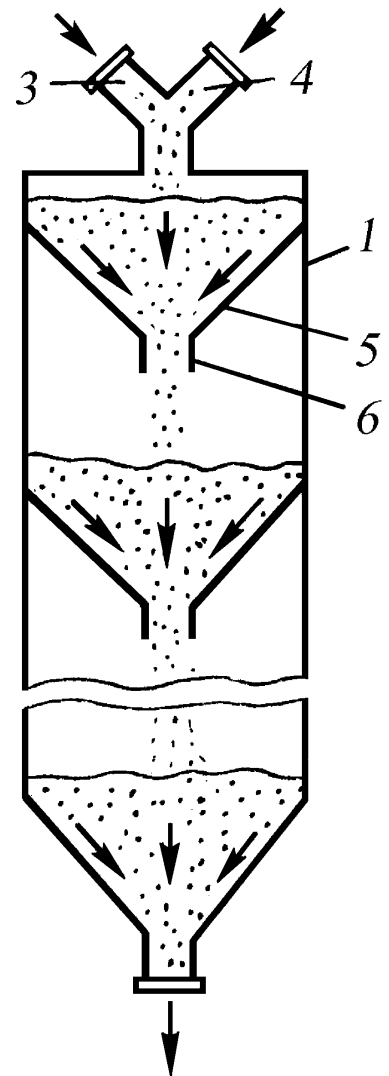

b)

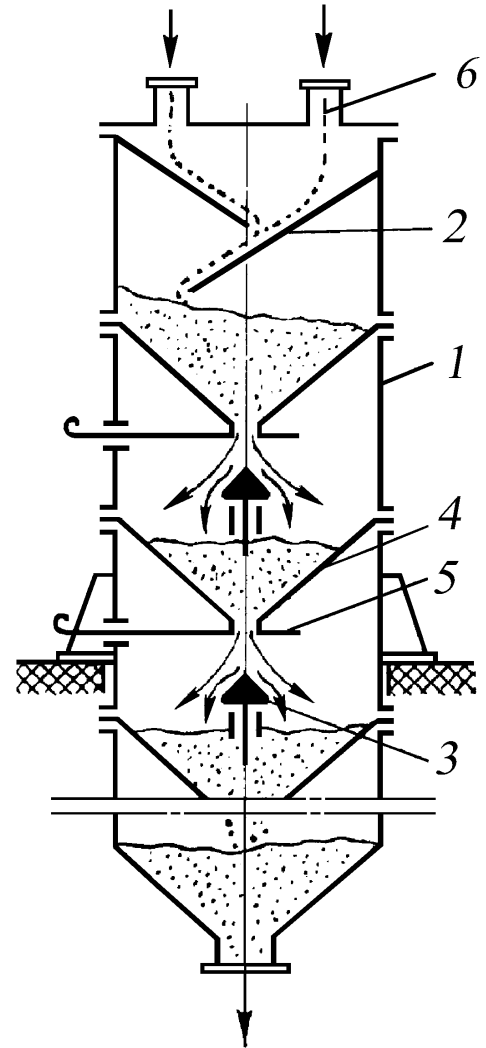

c)

Fig. 4. The schemes of the gravitation mixers: $a$-chute; $b$-bunker; $c$-blow-distributive 


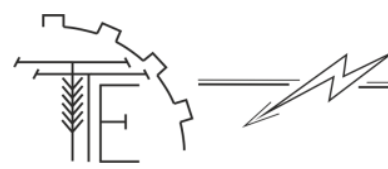

A wide spread equipment for micro-level mixing are vibration (fig 5, a) [2] and centrifugal (fig 5, b) [2] mixers. Their general shortcomings are: low productivity and complex construction. This equipment is intended mainly for preparation of dry heterogeneous dispersed mixtures. In an unbalanced drive of the vibration mixer absents possibility of separate independent regulation of frequency and amplitude of apparatus body oscillations, that limits technological possibilities of such mixers $[4,5]$. Their unbalanced vibration exciters are source of noise of increased level and of intensive wear of bearing units.



a)

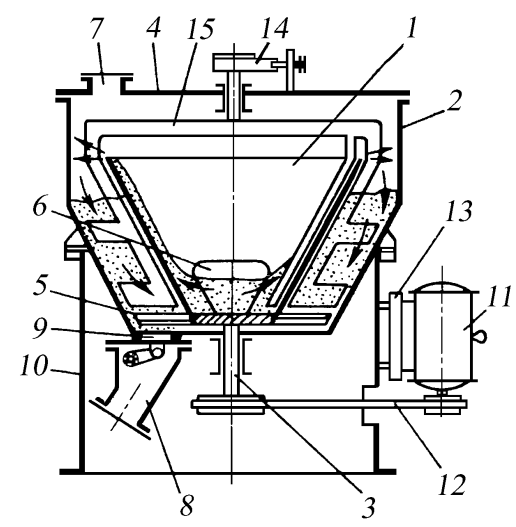

b)

Fig. 5. The schemes of the vibration (a) and the centrifugal (b) mixers

Working process in centrifugal mixers (fig. 5, b) demands of significant energy expenses.

At the basis of above conducted analysis we are coming to conclusion, that the most prospective prototypes for elaboration of an equipment for macro- and micro-level mixing of dry heterogeneous dispersed systems are gravitation mixers (fig. 4, c) and for effective preparation of liquid mixtures - screw mixers (fig. 2, b).

\section{Aim of research}

The aim of the research is to intensify the processes of mixing dry and liquid heterogeneous dispersed systems by developing, researching and introduction of an equipment with a combined mechanical and ultrasonic drive.

To achieve this aim, the following tasks were solved:

- taking into account the advantages and disadvantages of the known mixing equipment to offer schemes of apparatuses with combined drives for mixing dry and wet food mixtures at the macro- and microlevel, which allow simultaneously with mixing to carry out highly efficient heat transfer, diffusion and chemical processes;

- get dependencies that connect main design and operating parameters of the proposed apparatuses.

\section{Results of research}

The proposed scheme of an apparatus of combined gravitational-vibration action for mixing of dry food mixtures at the macro- and micro-level is presented at fig. 6. Components of mixture are fed in the apparatus through the sockets 1 of the body 2 . Then they slide over chutes 3 and get on the upper conical diaphragm 8. In this way is provided preliminary macro-level mixing of system components. Open flow area of the upper conical diaphragm can be regulated with help of the gate 5 with electromechanical drive. Value of the open flow area of the diaphragm is regulated in such way, that to provide filling of the upper conical diaphragm up to its upper cross section. There are four electromagnetic ultrasonic vibration exciters 4 installed in two vertical longitudinal sections of the upper conical diaphragm. Advantages of this type of vibration exciters are: relatively low price, compact dimensions, high efficiency and reliability, provision of possibility of independent wide range change of frequency and amplitude of executive element oscillations, wide range of power of serial industrial vibration exciters. The vibration exciters provide intensive oscillations of the conical diaphragm and particles of mixture components on it. This promotes to periodical uniform distribution of particles on the diaphragm surface with their mutual slippages, turnings, more tight pilling [5] and effective mixing at micro-level. Then mixture particles go through the upper conical diaphragm openings and fall on the surface of the oscillating cone 6 , connected with the electromagnetic ultrasonic vibration exciter 11 . It 


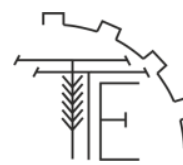

provides additional micro- and macro-level mixing of components particles. After that mixture particles go through partition openings 7 and fall on the middle conical diaphragm 8, which has same construction and operation principle as the upper conical diaphragm. The diaphragm 8 provides second macro- and micromixing of mixture components and more even distribution of its particles over a volume. The third stage of macro- and micro-mixing is realized on the lower conical diaphragm 13, which also equipped with the electromagnetic ultrasonic vibration exciters. Prepared mixture is fed out through the socket 14 in the lower part of the body 2 .

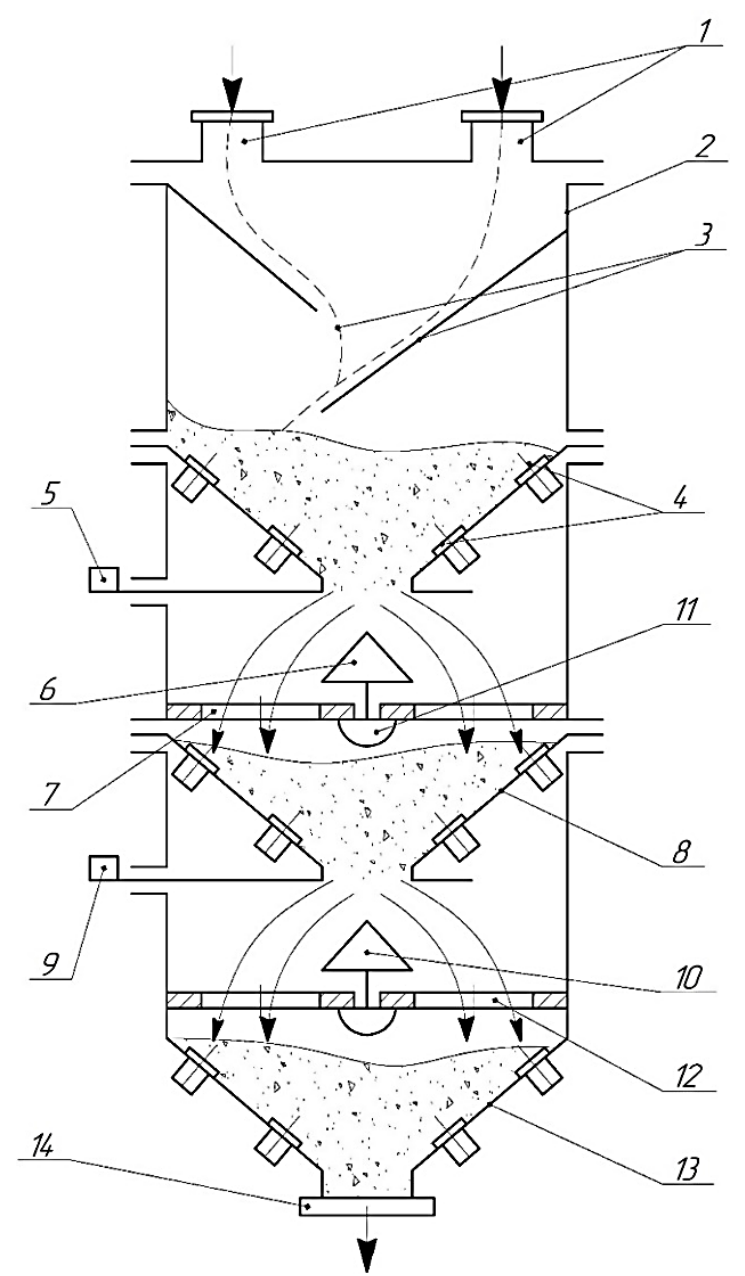

Fig. 6. The proposed scheme of the apparatus of combined gravitational-vibration action for mixing of dry food mixtures at the macro- and micro-level:

1 - loading sockets; 2 - body; 3 -inclined trays; 4, 11 - electromagnetic ultrasonic vibration exciters; 5, 9 -adjustable gate with electromechanical drive; 6, 10 -oscillating cones; 7, 12 - partitions with openings; 8,13 -conical diaphragms; 14 -unloading socket

The advantages of the proposed apparatus are: simple and reliable design, high productivity, absence of energy expenses for realization of macro-mixing, utilization in mixer design of serial details and units.

There are calculating schemes of mixture particle movement over a conical diaphragms surface under impact of driving force $F_{p}$ and nearby particles, relatively of coordinates axes $x$ and $y$ are presented at fig. 7 .

There are parameters, designated at the schemes (fig. 7):

$m_{p}, d_{p}$ - mass and diameter of a mixture particle with middle dimensions (in course of modeling we are taking assumption, that particles have right spherical form $[4,5])$;

$c_{p}, \mu_{p}$ - coefficients of rigidity and dry friction of the particle in course of its movement relatively nearby particles;

$\mu_{e}$ - coefficient of dry friction of the particle over the surface of the conical diaphragm;

$\sigma_{p}-$ yield point of the particle [6];

$\beta$ - angle of the conical diaphragm;

$h_{0}-$ high of the cylinder part of the diaphragm; 
$x_{p . n}-$ movement of the particle in course of a $n$-cycle of vibro-blowing loading of the particle, in course of stages of movements of executive element of electromagnetic vibration exciter from an initial position in a top position (I stage) and from the top position in the initial position;

$l_{c l}, l_{c 2}, l_{c 3}$ - length of areas of the conical diaphragm surface between of surfaces of executive elements of electromagnetic ultrasonic vibration exciters (see fig. 7, b);

$d_{v}$ - diameter of the executive element of the electromagnetic ultrasonic vibration exciter.

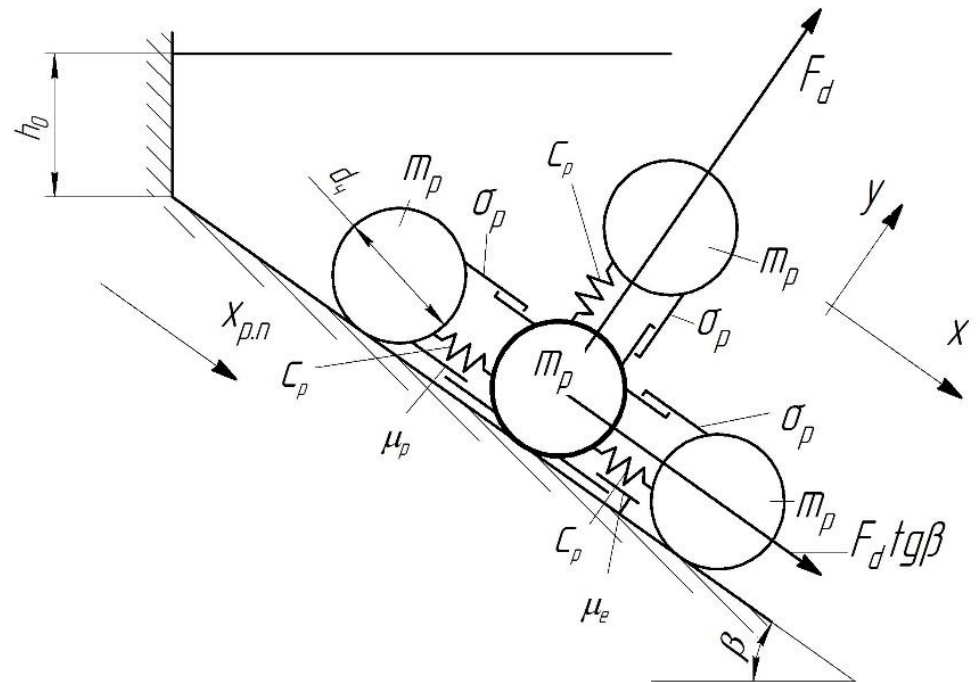

a)

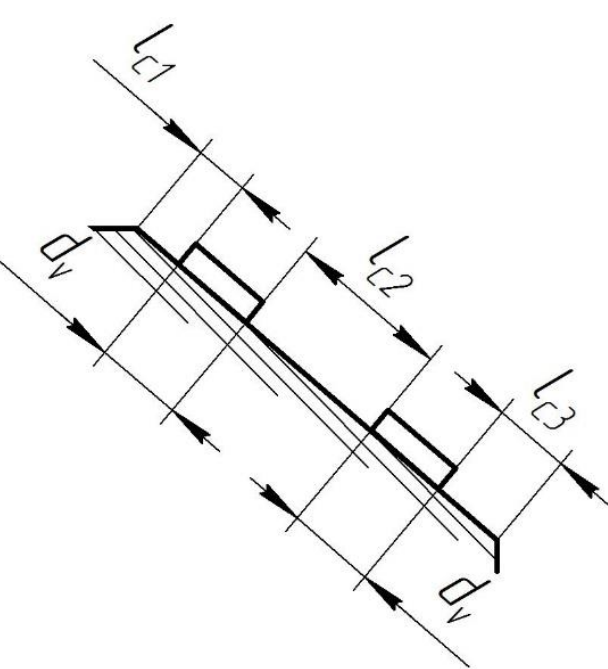

b)

Fig. 7. The calculating schemes of mixture particle movement over the conical diaphragms surface

Differential equations of particle movement relatively axis $x$ and $y$ over the surfaces of the executive elements of the electromagnetic ultrasonic vibration exciters, in course of the I stage of the $n$-cycle of exciter executive element movements are:

$$
\begin{gathered}
m_{p}\left(g \cdot \sin \beta-\ddot{x}_{p . n}\right)+\left(\ddot{y}_{p . n}+g \cdot \cos \beta\right)\left(\mu_{p}+\mu_{e}\right) \rho_{p} \frac{\pi \cdot d_{p}^{2}}{4}\left[h_{0}+\sin \beta\left(\sum_{i=1}^{n-1} x_{p . i}+x_{u . p}\right)\right]+c_{p} x_{p . n}+\sigma_{p}=F_{d} t g \beta \\
m_{p}\left(\ddot{y}_{p . n}+g \cdot \cos \beta\right)+c_{p} y_{p . n}+\sigma_{p}=F_{d} \\
l_{c 1} \leq\left(\sum_{i=1}^{n-1} x_{p . i}+x_{p . n}\right) \leq l_{c 1}+d_{v} ; l_{c 1}+l_{c 2}+d_{v} \leq\left(\sum_{i=1}^{n-1} x_{p . i}+x_{p . n}\right) \leq l_{c 1}+l_{c 2}+2 \cdot d_{v} ; 0 \leq t \leq \frac{1}{2 \cdot v}
\end{gathered}
$$

where $\rho_{p}-$ middle density of the mixture particle;

$v$ - circle frequency of executive element oscillations $[5,6]$.

Differential equations of particle movement relatively axis $x$ and $y$ over the surfaces of the executive elements of the electromagnetic ultrasonic vibration exciters, in course of the II stage of the $n$-cycle of exciter executive element movements are:

$$
\begin{gathered}
-m_{p}\left(\ddot{x}_{p . n}+g \cdot \sin \beta\right)+\left(\ddot{y}_{p . n}+g \cdot \cos \beta\right) \mu_{p} \rho_{p} \frac{\pi \cdot d_{p}^{2}}{4}\left[h_{0}+\sin \beta\left(\sum_{i=1}^{n-1} x_{p . i}+x_{p . n}\right)\right]-c_{p} x_{p . n}-\sigma_{p}=0 \\
-m_{p}\left(\ddot{y}_{p . n}+g \cdot \cos \beta\right)-c_{p} y_{p . n}-\sigma_{p}=0 \\
l_{c 1} \leq\left(\sum_{i=1}^{n-1} x_{p . i}+x_{p . n}\right) \leq l_{c 1}+d_{v} ; l_{c 1}+l_{c 2}+d_{v} \leq\left(\sum_{i=1}^{n-1} x_{p . i}+x_{p . n}\right) \leq l_{c 1}+l_{c 2}+2 \cdot d_{v} ; \frac{1}{2 \cdot v}<t \leq \frac{1}{v}
\end{gathered}
$$

Differential equations of particle movement relatively axis $x$ and $y$ over the conical diaphragm surface between of the surfaces of executive elements of the electromagnetic ultrasonic vibration exciters, in course of the I stage of the $n$-cycle of exciter executive element movements are: 


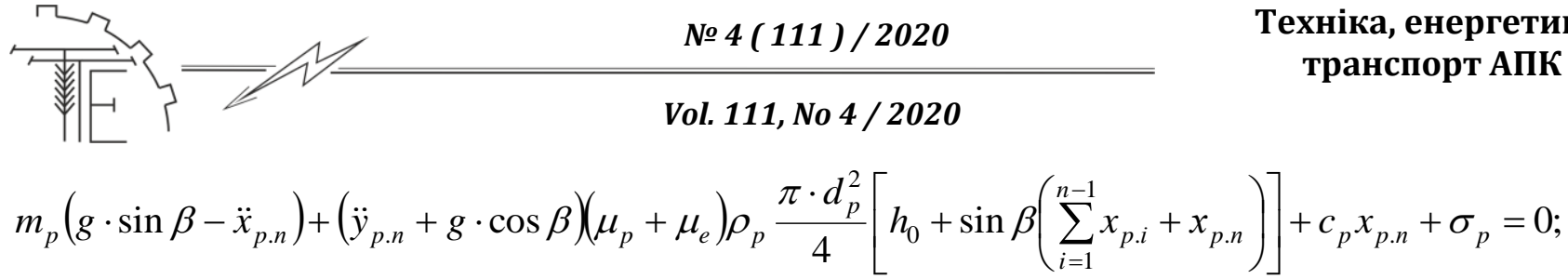

$$
\begin{aligned}
& m_{p}\left(\ddot{y}_{p . n}+g \cdot \cos \beta\right)+c_{p} y_{p . n}+\sigma_{p}=0 \text {; } \\
& 0 \leq\left(\sum_{i=1}^{n-1} x_{p . i}+x_{p . n}\right)<l_{c 1} ; l_{c 1}+d_{v}<\left(\sum_{i=1}^{n-1} x_{p . i}+x_{p . n}\right)<l_{c 1}+l_{c 2}+d_{v} \text {; } \\
& l_{c 1}+l_{c 2}+2 \cdot d_{v}<\left(\sum_{i=1}^{n-1} x_{p . i}+x_{p . n}\right)<l_{c 1}+l_{c 2}+l_{c 3}+2 \cdot d_{v} ; 0 \leq t \leq \frac{1}{2 \cdot v},
\end{aligned}
$$

Differential equations of particle movement relatively axis $x$ and $y$ over the conical diaphragm surface between of the surfaces of executive elements of the electromagnetic ultrasonic vibration exciters, in course of the II stage of the $n$-cycle of exciter executive element movements are:

$$
\begin{gathered}
-m_{p}\left(\ddot{x}_{p . n}+g \cdot \sin \beta\right)+\left(\ddot{y}_{p . n}+g \cdot \cos \beta\right) \mu_{p} \rho_{p} \frac{\pi \cdot d_{p}^{2}}{4}\left[h_{0}+\sin \beta\left(\sum_{i=1}^{n-1} x_{p . i}+x_{p . n}\right)\right]-c_{p} x_{p . n}-\sigma_{p}=0 \\
-m_{p}\left(\ddot{y}_{p . n}+g \cdot \cos \beta\right)-c_{p} y_{p . n}-\sigma_{p}=0 ; 0 \leq\left(\sum_{i=1}^{n-1} x_{p . i}+x_{p . n}\right)<l_{c 1} ; l_{c 1}+d_{v}<\left(\sum_{i=1}^{n-1} x_{p . i}+x_{p . n}\right)<l_{c 1}+l_{c 2}+d_{v} ; \\
l_{c 1}+l_{c 2}+2 \cdot d_{v}<\left(\sum_{i=1}^{n-1} x_{p . i}+x_{p . n}\right)<l_{c 1}+l_{c 2}+l_{c 3}+2 \cdot d_{v} ; \frac{1}{2 \cdot v}<t \leq \frac{1}{v} .
\end{gathered}
$$

There is a proposed scheme of an apparatus of combined mechanical-vibration action for preparation of liquid food mixtures at the macro- and micro-level, presented at the fig. 8.

The components of mixture are continuously loaded through the hopper 3 and then they are caught up with the screw mixer section 4 , that is brought in rotation from the electric motor 1 through the reducer 2 . The sections 4, 7, 9 of the apparatus provide macro-level mixing of components. The electromagnetic ultrasonic vibration exciters 6, 8 are fastened on internal body surfaces (no less than 4 vibration exciters in each body cross-section). The exciters realize mixing working process at micro-level. Ready mixture in continuous regime is unloaded from the apparatus through a socket in lower right part of its body.

Advantages of the proposed mixer (see fig. 8), as for the previous scheme (see fig. 6), are: simple and reliable design, checked by practice, high productivity, possibility of creation of the mixer at the base of a well known and distributed equipment.

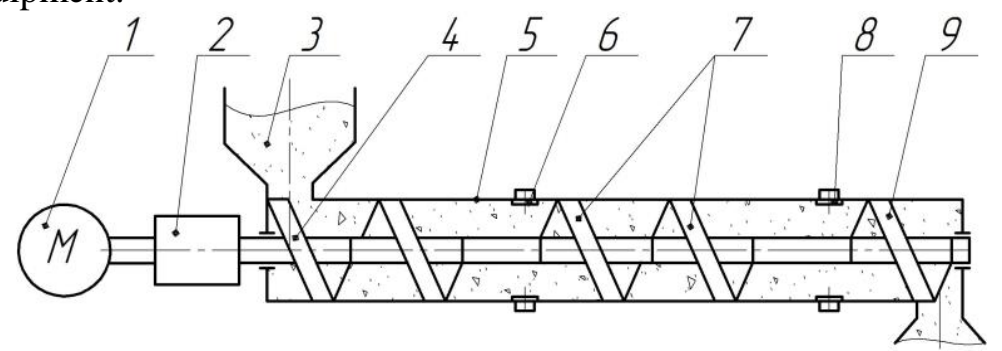

Fig. 8. The proposed scheme of the apparatus of combined mechanical-vibration action for mixing of liquid food mixtures at the macro- and micro-level:

1 -electric motor; 2 -reducer; 3 -loading hopper; 4, 7, 9 -sections of the screw mixer; 5 -mixer body; 6, 8 -electromagnetic ultrasonic vibration exciters

There are calculating schemes of mixture particle movement along of an internal surface of the apparatus body under the impact of the screw mixer and nearby particles, relatively coordinates axes $x$ and $y$ are presented at the fig. 9 .

There are parameters, designated at the schemes (fig. 9):

$m_{p}, d_{p}$ - mass and diameter of a mixture particle with middle dimensions;

$c_{p}, \alpha_{p}, \mu_{p}-$ coefficients of rigidity, viscous damping and dry friction of the particle in course of it movement relatively nearby particles;

$\mu_{b}$ - coefficient of dry friction of the particle over the body internal surface; 
$\sigma_{p}-$ yield point of the particle;

$\beta$ - incline angle of the screw turn [7];

$F_{s}, F_{v}$ - driving forces, which impact on the mixture particle from the screw mixer and from an executive element of an electromagnetic ultrasonic vibration exciter;

$l_{c 1}, l_{c 2}, l_{c 3}$ - length of areas of an internal surface of the mixer body between of the surfaces of the executive elements of the electromagnetic ultrasonic vibration exciters (see fig. 9, b);

$d_{v}$ - diameter of the executive element of the electromagnetic ultrasonic vibration exciter.



a)

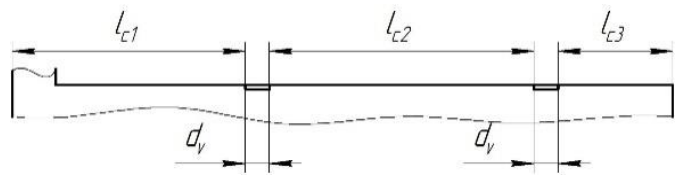

Fig. 9. The calculating schemes of the mixture particle movement along of the internal surface of the apparatus body under impact of the screw mixer and nearby particles, relatively coordinates axes $x$ and $y$

Differential equations of particle movement relatively axis $x$ and $y$ between of the surfaces of executive elements of the electromagnetic ultrasonic vibration exciters are:

$$
\begin{gathered}
-m_{p} \ddot{x}_{p}-\alpha_{p} \dot{x}_{p}-c_{p} x_{p}-\sigma_{p}-F_{s} \sin \beta\left(\mu_{p}+\mu_{b}\right)=F_{s} \cos \beta ; \\
\left\lfloor-m_{p} \ddot{y}_{p}-\alpha_{p} \dot{y}_{p}-c_{p} y_{p}-\sigma_{p}-F_{s}\left(\mu_{p}+\mu_{b}\right)\right] \cos \beta=F_{s} \sin \beta ; 0 \leq x_{p}<l_{c 1} ; \\
l_{c 1}+d_{v}<x_{p}<l_{c 1}+l_{c 2}+d_{v} ; l_{c 1}+l_{c 2}+2 \cdot d_{v}<x_{p}<l_{c 1}+l_{c 2}+l_{c 3}+2 \cdot d_{v} .
\end{gathered}
$$

Differential equations of particle movement relatively axis $x$ and $y$ over the surfaces of the executive elements of the electromagnetic ultrasonic vibration exciters, in course of the I stage of the $n$-cycle of exciter executive element movements are:

$$
\begin{gathered}
-m_{p} \ddot{x}_{p}-\alpha_{p} \dot{x}_{p}-c_{p} x_{p}-\sigma_{p}-\left(F_{s}-F_{v}\right) \sin \beta\left(\mu_{p}+\mu_{b}\right)=F_{s} \cos \beta ; 0 \leq t \leq \frac{1}{2 \cdot v} ; \\
l_{c 1} \leq x_{p} \leq l_{c 1}+d_{v} ; l_{c 1}+l_{c 2}+d_{v} \leq x_{p}<l_{c 1}+l_{c 2}+2 \cdot d_{v},
\end{gathered}
$$

where $v$ - circle frequency of executive element oscillations.

Differential equations of particle movement relatively axis $x$ and $y$ over the surfaces of the executive elements of the electromagnetic ultrasonic vibration exciters, in course of the II stage of the $n$-cycle of exciter executive element movements are:

$$
\begin{gathered}
\left\lfloor-m_{p} \ddot{y}_{p}-\alpha_{p} \dot{y}_{p}-c_{p} y_{p}-\sigma_{p}-\left(F_{s}-F_{v}\right)\left(\mu_{p}+\mu_{b}\right)\right\rfloor \cos \beta=F_{s} \sin \beta-F_{v} ; \frac{1}{2 \cdot v}<t \leq \frac{1}{v} . \\
l_{c 1} \leq x_{p} \leq l_{c 1}+d_{v} ; l_{c 1}+l_{c 2}+d_{v} \leq x_{p}<l_{c 1}+l_{c 2}+2 \cdot d_{v} .
\end{gathered}
$$

\section{Conclusions}

1. A known equipment for mixing of heterogeneous dry and liquid food mixtures has in most cases insufficient universality in realization of working process both at macro- and at micro-level, that is especially important when the mixing is accompanied with thermal, diffusion or chemical processes. Besides the most part of modern industrial mixing machines have not enough simple and reliable construction.

2. Authors of the article are proposing schemes of improved mixing apparatuses, which can be created at the base of industrial mixers by way of their additional equipment with serial electromagnetic ultrasonic vibration exciters and which provide effective working process at macro- and at micro-level.

3. There are differential equations of a mixture particle movements in a working chamber of the proposed apparatuses relatively two coordinates axis and in course of different stages of oscillation cycle of 


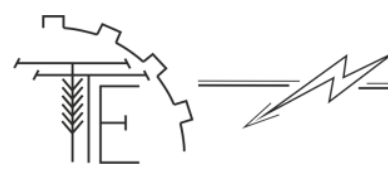

Vol. 111, No 4 / 2020

executive elements of the vibration exciters are presented in the article. These equations can be used for elaboration of methods of design calculation of the proposed apparatuses.

\section{References}

[1] Antipov, S. T., Kretov, I. T., Ostrikov, A. N. (2001). Mashiny i apparaty pishchevyh proizvodstv [Machines and apparatuses of food productions]. In 2 vol. Vol. 1. Moskow: Vysshaya shkola [in Russian].

[2] Ostrikov, A.N., Krasovickij, Yu.V., Petrov, S.M. (2006) Processy i apparaty pishchevyh proizvodstv [Processes and apparatuses of food productions]. In 2 vol. Vol. 2. Sankt-Peterburg: GIORD [in Russian].

[3] Sevostyanov, I. V., Zozulyak, I. A. (2020) Tekhnologichne obladnannya cekhiv pererobki produkcii tvarinnictva [Technological equipment of processing work shop of breeding products]. Vinnycia : VNAU [in Ukrainian].

[4] Sevostyanov, I. V. (2020) Tekhnologiya ta obladnannya dlya vibroudarnogo znevodnennya vologih dispersnih materialiv [Technology and equipment for vibro-blowing dehydration of damp dispersive materials]. Vinnycia : VNAU [in Ukrainian].

[5] Sevostyanov, I. V. (2013) Processy i oborudovanie dlya vibroudarnogo razdeleniya pishchevyh othodov [Processes and equipment for vibro-blowing separation of food waste]. Saarbrüken: LAB LAMBERT Academic Publishing, [in Russian].

[6] Sevostianov, I., Ivanchuck, Ya., Kravets, S. (2020) Elaboration and researches of highly effective installation for vibro-blowing dehydration of dispersive waste of food productions. 3 (110), $24-33$. Tekhnika, energetika, transport APK.

[7] Aminov, M. S. (1999) Processy i apparaty pishchevyh proizvodstv [Processes and apparatuses of food productions]. Moskow: Kolos [in Russian].

[8] Sevostyanov, I. V., Lucik, V. L. (2017) Ustanovka dlya bagatostadijnogo znevodnennya vidhodiv harchovih virobnictv [Installation for multi-stage dehydration of food productions waste]. 1, 105 - 113. Visnik mashinobuduvannya ta transportu [in Ukrainian].

\section{Список використаних джерел}

1. Антипов С. Т., Кретов И. Т., Остриков А. Н. Машины и аппараты пищевых производств. В 2 кн. Кн. 1/ Под ред. Акад. РАСХН В. А. Панфилова. Москва: Высшая школа, 2001. 703 с.

2. Остриков А.Н., Красовицкий Ю.В., Петров С.М. Процессы и аппараты пищевых производств. В 2 кн. Кн. 2: Учеб. для вузов / и др. Под ред. А.Н. Острикова. Санкт-Петербург: ГИОРД, 2006. 559 c.

3. Севостьянов I. В., Зозуляк I. А. Технологічне обладнання цехів переробки продукції тваринництва. Навчальний посібник. Вінниця : ВНАУ, 2020. 127 с. ISBN 978-617-7789-16-0.

4. Севостьянов I. В. Технологія та обладнання для віброударного зневоднення вологих дисперсних матеріалів : монографія. Вінниця : ВНАУ, 2020. 303 с.

5. Севостьянов И. В. Процессы и оборудование для виброударного разделения пищевых отходов. Монография. Saarbrüken: LAB LAMBERT Academic Publishing, 2013. 417 c.

6. Sevostianov I., Ivanchuck Ya., Kravets S. Elaboration and researches of highly effective installation for vibro-blowing dehydration of dispersive waste of food productions. Техніка, енергетика, транспорт АПК, 2020. №3 (110). С. 24-33.

7. Аминов М. С. Процессы и аппараты пищевых производств. М.: Колос, 1999. 504 с.

8. Севостьянов І. В., Луцик В. Л. Установка для багатостадійного зневоднення відходів харчових виробництв. Вісник машинобудування та транспорту, 2017. №1. С. 105-113.

\section{ІНТЕНСИФІКАЦІЯ ЗМІШУВАННЯ НЕОДНОРІДНИХ ХАРЧОВИХ СУМІШЕЙ ПІД ВПЛИВОМ УЛЬТРАЗВУКОВОЇ ВІБРАЦІї}

У статті аналізується відоме обладнання для перемішування неоднорідних харчових сумішей. Частина иього обладнання забезпечує якісне перемішування на макро-рівні (змішування великих пориій оброблюваного матеріалу), наприклад, лопатеві, пропелерні, турбінні, якірні, гвинтові, гравітаційні $і$ барабанні змішувачі. Інша частина змішувальних машин, навпаки, дозволяє домогтися ефективного перемімування на мікро-рівні (взаємні переміщення сусідніх частинок матеріалу) - вібраційні $i$ відиентрові змішувачі. У деяких випадках важливо забезпечити добре перемішування як на макро-, так і на мікро-рівні, особливо, коли воно супроводжується тепловими, дифузійними або хімічними прочесами та від його ефективності залежать енерговитрати і якісні характеристики продукту. Таким чином, в статті вирішується завдання розробки схем вдосконалених установок для 


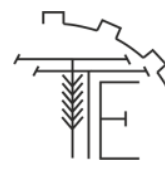

ефективного макро- і мікро-перемішування сухих і рідких багатокомпонентних матеріалів. Автори пропонують створювати иі установки на базі відомого обладнання - гравітаційних та шнекових змімувачів, шляхом їх додаткового оснащення серійними електромагнітними віброзбуджувачами ультразвукових коливань. В результаті головний привід базового змішувача буде забезпечувати робочий прочес на макрорівні, а додатковий привід - переміщення частинок матеріалу на мікро-рівні. Пропоновані установки мають просту та надійну конструкиію, не містять орихінальних деталей $i$, в той же час, забезпечують необхідну ефективність робочого процесу. У статті також представлені рівняння руху частинок оброблюваного матеріалу на різних етапах його навантаження з врахуванням фізико-механічних властивостей матеріалу. Ці рівняння можуть бути використані як основа для подальшого створення методик проектного розрахунку пропонованих установок.

Ключові слова: неоднорідні харчові суміші, перемішування на макро- та мікрорівні, електромагнітний віброзбуджувач, ультразвукові коливання.

Ф. 7. Рuc. 9. Лim. 8.

\section{ИНТЕНСИФИКАЦИЯ СМЕШИВАНИЯ НЕОДНОРОДНЫХ ПИЩЕВЫХ СМЕСЕЙ ПОД ВОЗДЕЙСТВИЕМ УЛЬТРАЗВУКОВОЙ ВИБРАЦИИ}

В статье анализируется известное оборудование для перемешивания неоднородных пищевых смесей. Часть данного оборудования обеспечивает качественное перемешивание на макро-уровне (смешивание больших пориий обрабатываемого материала), например, лопастные, пропеллерные, турбинные, якорные, винтовые, гравитационные и барабанные смесители. Другая часть смесительных машин, напротив, позволяет добиться эффективного перемешивания на микро-уровне (взаимные перемещения соседних частии материала) - вибрационные и центробежные смесители. $B$ некоторых случаях важно обеспечить хорочее перемешивание как на макро-, так и на микро-уровне, в особенности, когда оно сопровождается тепловыми, диффузионными или химическими прочессами и от его эффективности зависят энергозатраты и качественные характеристики продукта. Таким образом, в статье решается задача разработки схем усовершенствованных установок для эффективного макро- и микро-перемешивания сухих и жидких многокомпонентных материалов. Авторы предлагают создавать эти установки на базе известного оборудования - гравитаиионных и шнековых смесителей, путем их дополнительного оснащения серийными электромагнитными вибровозбудителями ультразвуковых колебаний. В результате главный привод базового смесителя будет обеспечивать рабочий прочесс на макро-уровне, а дополнительный привод - перемещения частии материала на микро-уровне. Предлагаемые установки имеют простую и надежную конструкиию, не содержат оригинальных деталей и в то же время обеспечивают необходимую эффективность рабочего процесса. В статье также представлены уравнения движения частич обрабатываемого материала на различных этапах его нагружения с учетом физико-механических свойств материала. Эти уравнения могут быть использованы как основа для дальнейшего создания методик проектного расчета предлагаемых установок.

Ключевые слова: неоднородные пищевые смеси, перемешивание на макро- и микро-уровне, электромагнитный вибровозбудитель, ультразвуковые колебания.

Ф. 7. Puc. 9. Лит. 8 .

\section{ВІДОМОСТІ ПРО АВТОРІВ}

Севостьянов Іван Вячеславович - доктор технічних наук, завідувач кафедри «Технологічних процесів та обладнання переробних і харчових виробництв» Вінницького національного аграрного університету (вул. Сонячна, 3, м. Вінниця, 21008, Україна, e-mail: ivansev70@ gmail.com).

Краєвський Сергій Олександрович - аспірант Вінницького національного аграрного університету (вул. Сонячна, 3, м. Вінниця, 21008, Україна, e-mail: skraevsky4@gmail.com).

Севостьянов Иван Вячеславович - доктор технических наук, профессор кафедры «Технологических процессов и оборудования перерабатывающих и пищевых производств» Винницкого национального аграрного университета (ул. Солнечная, 3, г. Винница, 21008, Украина, e-mail: ivansev70@ gmail.com). Краевский Сергей Александрович - аспирант Винницкого национального аграрного университета (ул. Солнечная, 3, г. Винница, Винницкая область, 21008, Украина, e-mail: skraevsky4@ gmail.com).

Sevostyanov Ivan - Doctor of Technical Sciences, Full Professor of the Department of "Technological Processes and Equipment of Processing and Food Productions" of Vinnytsia National Agrarian University (3 Solnechnaya St, Vinnytsia, 21008, Ukraine, e-mail: ivansev70@gmail.com).

Kraevsky Sergiy - Post-Graduate Student of Vinnytsia National Agrarian University (3, Solnychna str., Vinnytsia, Ukraine, 21008, e-mail: skraevsky4@gmail.com). 